\title{
The Management Of Sustainable Development at Malaysian Local Government: Stakeholders' Perception
}

\author{
Sulzakimin Mohamed ${ }^{1}$,Seow Ta Wee*, Goh Kai Chen, \\ Md Asrul Nasid Masrom, Mohd Hilmi Izwan Abd Rahim \\ 1zakimin@uthm.edu.my \\ University Tun Hussein Onn Malaysia \\ *tawee@uthm.edu.my
}

Keywords: sustainable development, stakeholders, local government

\begin{abstract}
Sustainable development has become an important aspect of the construction industries. There are many ways sustainability elements can be incorporated in the design, construction, operation and deconstruction of a building. Importantly sustainability represents the link between society and built environment professionals. In relation to that, this study involves a look at the stakeholders' outlook and interaction with sustainability from local governments. In this study, the focus is on the role of the Local Governments and how the perception of the stakeholders. Therefore, this study intend to look into the sustainable development and better understanding the strength and weaknesses and other relevant factors that promote or hinder the Sustainable Development using the interview with selected stakeholders. This study is to contribute to the enrichment of knowledge on the role of Local Governments in Sustainable Development. Therefore, this research find out that Malaysian Local Governments need to improve in terms of knowledge as well as the enforcement towards Sustainable Development.
\end{abstract}

\section{INTRODUCTION}

The notion of sustainable development in terms of knowledge transfer in local governments has become the topic discourse in academic research, business fields and governance, where as suggested by [1][2][3], Knowledge transfer describes how knowledge and ideas move between the knowledge sources to the potential users of that knowledge. In general terms, knowledge can be transferred by moving a knowledge reservoir from one unit to another or by modifying a knowledge reservoir at a recipient site. Staff members can be moved from one unit to another. Similarly, technology can be moved and routines can be transported from one organization to another. Hence, through communication and training, the knowledge transfer is existed.

Moreover, local government takes responsibility for the environment, social and economic development of the country [4][5]. The local government through the policy, programs, plans, and strategies oriented people to choose sustainable development. However, sustainable development cannot develop without an appropriate knowledge in government. Hence, knowledge transfer can be thought of as a cycle where knowledge is communicated around in the organization and to the community via a variety of methods. Although knowledge transfer differs greatly between fields, there are several factors which are needed to make any knowledge transfer practices successful [6][7][8]. It means that the organization must understand the context of the new knowledge generated. For example, the importance of sustainability takes on increased relevance to knowledge of the staff as well as the policy makers when viewed in the context of development and as a solution for next generation. Moreover, it is crucial working at various levels of management to promote the sustainable development of local government. This study aims to study the perceptions of stakeholders of sustainable development at Malaysian local government practices. 


\section{Background Study}

The transferring of knowledge in the local governments to address the needs and challenges of the sustainability is considered as one of the most important aspects of this research. This research was conducted to study knowledge transfer practices of sustainable development in local governments. Understanding the practices and how actions affect the organizations and its impact are crucial to answer the research objectives.

In addition, the lack of knowledge transfer in Malaysian local governments has jeopardized the overall implementation of development in local government [9]. The knowledge must both be learned and be useable in a relevant context, if both conditions do not exist, the knowledge has not been transferred [10][11]. It means that shortage of knowledge in sustainable development may lead to the local governments' staffs unfavorable to implement it. The spreading of knowledge on the preservation of resources and protection of the environment through schools, universities and ongoing training organizations are essential [12][13][14][15]. It means that supporting the development of operational training sectors and encourages transfers of skills for the benefit of all through dedicated programme such LA21 are great for knowledge transfer practice. Therefore, the knowledge transfer and management are crucial for local governments to fulfill sustainable development agenda.

[11] iterates that people use their capacity-to-act in order to create value in mainly two directions; by transferring and converting knowledge externally and internally to the organisation. It means that by introducing knowledge transfer practices, many organizations could improve the flows of knowledge around their organization, make it accessible when and where needed, and use it to add sustainability value, such as through planning development, improved development processes or new products and services. Thus the knowledge transfer practices of sustainable development could help stakeholders to become more effective with sustainability deliverable.

Apart from that, sustainable development requires the participation of diverse stakeholders and perspectives with ideal and subsequent coordination of mutual action to achieve multiple values [16][17]. It means that if local governments' lacking in managing the knowledge of sustainable development, the negatives consequences could occur. It shows that, local governments and its stakeholders must have mutual coordination in order to manage knowledge of sustainable development. Moreover, local governments are where the local community infrastructure underpins the nation's economy and provides significant support to the state and national development projects [18][19][20]. This means that local governments should be able to deliver the services and increasing the stakeholders' belief.

\section{Methodology}

Step 1 is literature review and desk research. Information will be gathered from academics journal, publication, related articles, and documentary and government reports where available. Step 2 is using survey method which is interview. Survey data can be collected either through faceto face interview, telephone interview or postal questionnaire [21][22][23][24]. This study looks into the practice of Malaysian local governments through stakeholder's perception. Therefore, literature reviews inform researchers of the background to their research projects and provide context and ideas for their studies. The preliminary information gathering is conducted by reviewing relevant literature, which helped the researcher to understand and gain a wide view of possible research problems [25]. There are good reasons for spending time and effort on a review of the literature before embarking on a research project. These reasons include; to uncover the gaps in the literature, to carry on from the point others have already reached (reviewing the field allows the research to build on the platform of existing knowledge and ideas), to identify information and ideas that may be relevant to the research, and to identify methods that are relevant to the research.

This study is to get an insight from the sources such as from Public Work Department, Architect organisations, other related government agencies and private sectors that are the stakeholders of local governments. The agencies selected are based on the discussion with the Local Governments and those selected are organization that have close relationship or networking with local governments. Sample is taken using the data from the planning approval committee where the 
organization is involved in the committee to approve the planning development at local government. It was not necessary to interview all the staff since the simple sampling strategy would be sufficient to represent the data required for the study [26][27]. Therefore, the researcher comes out with these eight agencies as shown in Table 1.1. These eight agencies have close relationship with local governments in terms of sustainable development and fit the requirement for this study. In Table 1.1, it shows the selected organisation as a subject and the respondents are selected from it. The respondents are selected based on their unit/division and their post.

Table 1.1: Interviewee's Name

\begin{tabular}{ll}
\hline Agencies' name & No of Respondent \\
\hline 1 PWD(Public Works Department) & $\mathbf{1}$ \\
2 CIDB (Construction Industry Board) & $\mathbf{1}$ \\
3 SIME DARBY & $\mathbf{1}$ \\
4 TNB(Tenaga Nasional Berhad) & $\mathbf{1}$ \\
5 PAM(Persatuan Arkitek Malaysia) & $\mathbf{1}$ \\
6 KETTHA(Kementerian Tenaga, Teknologi & $\mathbf{1}$ \\
Hijau dan Air) & $\mathbf{1}$ \\
7 PTM(Pusat Tenaga Malaysia) & $\mathbf{1}$ \\
8 Department of Irrigation and Drainage & $\mathbf{1}$ \\
9 Developers & $\mathbf{9}$ \\
TOTAL & \\
\hline
\end{tabular}

It means that selecting people or elements from a population in such a way that each individual has an equal chance or probability of selection [28][29]. Selection of the respondents was based on the position in the department and work scope.

\section{Result}

Table 1.1: Perceptions of Stakeholders

\begin{tabular}{ll}
\hline Human Capital & Perceptions of Stakeholders \\
& $\begin{array}{l}\text { Need to get people involved in sustainable development. } \\
\text { Local governments, businesses and citizens need to shift their focus away } \\
\text { from the unrestrained accumulation of goods, and toward finding ways to } \\
\text { ensure a sustainable and better life for all. } \\
\text { Different roles in and around a planning approval should stamp their } \\
\text { influence on adhering to sustainability principles. } \\
\\
\text { Local governments must be the forefront of sustainable development in } \\
\text { terms of the expertise in their organization and be the expert networking } \\
\text { channel or link between local governments and other agencies. }\end{array}$ \\
$\begin{array}{l}\text { Refocusing the view of business and examining how to sustainably handle it } \\
\text { Technology }\end{array}$ & $\begin{array}{l}\text { as mastering the process or matter in sustainable development. } \\
\text { Application }\end{array}$ \\
Act/policy/rules & $\begin{array}{l}\text { Need to communicate their sustainable goals, visions and strategies, in other } \\
\text { words need to exercise good management and be transparent about what } \\
\text { they want to achieve. } \\
\text { Need to keep the dialogue open or public participations based on the } \\
\text { appropriate policy. }\end{array}$ \\
\hline
\end{tabular}

Table 1.1 shows that the perceived view of respondents in terms of the principle of sustainable development and what is it related to most disperse for the sustainability principles in building and environment. Respondents mention that sustainability is generally understood to mean something along the lines of not consuming resources faster than their production and not polluting the environment in an irreversible way. Respondents also mention relevant activity through numerous partnerships with local governments should be encouraged which could assists in the development 
of a new sustainable technologies Accordingly, The Brundtland report on definition of sustainability has open to interpretation, which probably has helped popularize sustainability but has also made it difficult for groups with different priorities to agree on a common course of action [30][31][32]. Moreover, they argue that the lack of consensus has also complicated attempts to measure the effectiveness of sustainability efforts and make comparisons across programs and geographies. A growing body of knowledge on sustainable development, however, is providing the means to better understanding of current conditions and demonstrate progress as the respondents explain. Moreover, they believe that the principle of sustainable development is to overcome the growing concern over the negative impact of human activity on the environment. Relatively, the respondents mention about the deteriorating condition of the environment that has lead to a widespread public awareness on the need for local governments to identify global solutions for the environmental issues. Overall, the respondents mention about the lack of local governments 'role play in fostering citizen participation in the communities they serve and should considers how to promote sustainable development to public. It means that the identification of these perspectives not only allows for the accurate portrayal of the local governments' role in administration, but also to enhance the knowledge transfer practice of sustainable development through an increased understanding of local governments' staff and stakeholders. In addition, the interview reveal that sustainable development support a more networking through sharing of expertise in the planning approval process. Moreover, it is necessary to implement the sustainable solutions across the planning approval's committee to encourage the development of knowledge, the transfer of skills and innovation of sustainable development.

The spreading of knowledge on the preservation of resources and protection of the environment through schools, universities and ongoing training organizations are essential [12][13][14][15]. It means that supporting the development of operational training sectors and encourages transfers of skills for the benefit of all through dedicated programme such LA21 are great for knowledge transfer practice. Respondents also mention relevant activity through numerous partnerships with local governments should be encouraged which could assists in the development of a new sustainable technologies. The respondents mention that by applying knowledge of sustainable development, it will sustain the communities and derive benefit from an increasingly complex future. Therefore, the resources in terms of budget, people, technology and act/policy/rules should be able to face economic viability, deteriorating infrastructure, natural disasters, environmental pollution, social disintegration, loss of community, crime and violence, urban blight, and unmanaged growth as perceived by stakeholders. Hence, the knowledge created at planning approval could support sustainability by means of knowledge transfer.

\section{Acknowledgment}

I wish to acknowledge the commendable initiatives taken by Faculty of Technology Management \& Business (FPTP), University of Tun Hussein Onn Malaysia (UTHM) for the sponsorship as well as the support. The sponsorship for conference's fee is beneficial for the interests and in motivating the academic staff. Being a researcher, the sponsorship could assume an important role in inculcating the research culture of academic staff of UTHM.

\section{References}

[1] Hester, A. (2008). Innovating with Organizational Wikis : Factors Facilitating Adoption and Diffusion of an Effective Collaborative Knowledge Management System. Knowledge Creation Diffusion Utilization, 161-163. doi:10.1145/1355238.1355278

[2] Osterloh, M., \& Frey, B. S. (2007). Motivation , Knowledge Transfer , and Organizational Forms, 11(5), 538-550.

[3] Yuan, M., \& Yang, J. (2009). A Knowledge Management Framework to Promote Infrastructure Project Sustainability. In CRIOCM2009 INTERNATIONAL SYMPOSIUM ON ADVANCEMENT OF CONSTRUCTION MANAGEMENT AND REAL ESTATE VOLS 16 (Vol. 16, pp. 2480-2486).

[4] Milutinovic, S. (2010). Local sustainable development planning in Serbia: Achievements so far and future challenges. Thermal Science, 14, 579-592. doi:10.2298/TSCI091117004M 
[5] Streib, G. D., \& Willoughby, K. G. (2005). Local governments as e-governments: Meeting the implementation challenge. Public Administration Quarterly, 29, 77-109.

[6] Bender, S., \& Fish, A. (2000). The transfer of knowledge and the retention of expertise: the continuing need for global assignments. Journal of Knowledge Management, 4, 125.

[7] Donate, M. J., \& Guadamillas, F. (2010). The Effect of Organizational Culture on Knowledge Management Practices and Innovation. Knowledge and Process Management, 17, 82-94. doi: $10.1002 / \mathrm{kpm}$

[8] Liyanage, C., Ballal, T., Elhag, T., \& Li, Q. (2009). Knowledge communication and translation: A knowledge transfer model. Journal of Knowledge Management, 13, 118-131.

[9] Mohamed, S., Seow, T. W., \& Goh, K. C. (2013). The management of sustainable development: Malaysian local governments role. In MATRA (pp. 1-3). USM.

[10] Mohamed, S, Seow, T.W \& Goh, K.C. (2013). The Perceptions of Stakeholders at Knowledge Transfer of Sustainable Development in Malaysian Local Government's Planning Approval. 1 st Postgraduate Seminar FPTP. FPTP, UTHM, Batu Pahat, Johor.

[11] Sveiby, K.-E. (2001). A knowledge-based theory of the firm to guide in strategy formulation. Journal of intellectual capital, 2(4), 344-358.

[12] Barrutia, J., Aguado, I., \& Echebarria, C. (2007). Networking for Local Agenda 21 implementation: Learning from experiences with Udaltalde and Udalsarea in the Basque autonomous community. Geoforum, 38, 33-48. doi:10.1016/j.geoforum.2006.05.004

[13] Mohamed, S, Seow, T.W \& Goh, K.C. (2013). The Management of Sustainable Development: Malaysian Local Government's Role. Selected Issues on Health and Environment, Universiti Pendidikan Sultan Idris.

[14] Dale, A., \& Newman, L. (2005). Sustainable development, education and literacy. International Journal of Sustainability in Higher Education, 6, 351-362. doi:10.1108/14676370510623847

[15] Olsson, J. (2009). Sustainable development from below: institutionalising a global ideacomplex. Local Environment, 14, 127-138. doi:10.1080/13549830802521436

[16] Hawkins, C. V, \& Wang, X. (2011). Sustainable Development Governance: Citizen Participation and Support Networks in Local Sustainability Initiatives. Public Works Management Policy, 17, 7-29. doi:10.1177/1087724X11429045

[17] Segger, M.-C. C. (2004). Significant developments in sustainable development law and governance: A proposal. Natural Resources Forum, 28(1), 61-74. doi:10.1111/j.01650203.2004.00072.x

[18] Evans, B. O. B., \& Theobald, K. (2003). Policy And Practice Lasala: Evaluating Local Agenda 21 in Europe. Journal of Environmental Planning and Management, 46(September), 781-794. doi:10.1080/0964056032000138481

[19] OECD, S. S. D. (2007). Institutionalising Sustainable Development. Sustainable Development, 44, 135-141. doi:10.1787/9789264019096-en

[20] Sola, P. (2005). The Community Resource Management Plan: A tool for integrating IKS into natural resource management. Ethnobotany Research and Applications, 3, 143-153.

[21] Bryman, A. (2008). Mixed methods research: combining quantitative and qualitative research. In Social Research Methods (Vol. 3rd, pp. 608-626).

[22] Yang, Z., Liuyanping, \& Jie, T. (2008). Research on the Choice of Knowledge Transfer Models in Strategic Alliance. In R. Chi (Ed.), proceedings of 2008 international conference on risk and reliability management vols $\mathrm{i}$ and ii (pp. 476-480). universe academic press toronto.

[23] Yates, S. J. (2004). Doing Social Science Research. Social Science (Vol. 1, p. 293).

[24] Yin, R. K. (2009). Case Study Research: Design and Methods. Essential guide to qualitative methods in organizational research (Vol. 5, p. 219). doi:10.1097/FCH.0b013e31822dda9e 
[25] Chua, L. C. (2006). Sample size estimation using krejcie and morgan and cohen statistical power analysis: a comparison. Chua Lee Chuan Jabatan Penyelidikan. Jurnal Penyelidikan IPBL, 7, 78-86.

[26] Doyle, A. (2012). Behavioral Interviews. Aboutcom Job Searching.

[27] Smith, A. (2005). Interactive Qualitative Analysis: A Systems Method for Qualitative Research. Organizational Research Methods, 8, 481.

[28] Lin, W., \& Ryzin, G. G. (2011). Web and Mail Surveys: An Experimental Comparison of Methods for Nonprofit Research. Nonprofit and Voluntary Sector Quarterly. doi:10.1177/0899764011423840

[29] Teddlie, C., \& Yu, F. (2007). Mixed Methods Sampling: A Typology With Examples. Journal of Mixed Methods Research, 1,77-100. doi:10.1177/2345678906292430

[30] Adams, W. M. (2012). The Future of Sustainability: Re-thinking Environment and Development in the Twenty-First Century. In Sustainability (pp. 71-78).

[31] Harris, F. (2012). Sustainable Development: Negotiating the Future. In Global Environmental Issues (pp. 275-294). doi:10.1002/9781119950981.ch11

[32] Hopwood, B., Mellor, M., \& O'Brien, G. (2005). Sustainable development: mapping different approaches. Sustainable development, 13(1), 38-52. 